\title{
A natureza da política em Shakespeare e Maquiavel
}

\section{MIGUEL CHAIA}

$\mathrm{P}$

OR QUE RETOMAR Shakespeare e Maquiavel numa época em que a política opera fundamentalmente a partir de uma macroabordagem, com destaque para os sistemas políticos e as ideologias, e quando as preocupaçóes estão voltadas para o funcionamento das instituiçōes, a conquista da cidadania $e$ o controle das massas? Esses dois autores indicam rumos para a resposta: Maquiavel, na dedicatória de $O$ principe a Lorenzo de Medici, afirmando que o livro não quer outra coisa que o valorize "a não ser a variedade da matéria e a gravidade do assunto a tornarem-no agradável"; e Shakespeare, ao alertar em Hamlet, que "o tempo está fora dos eixos" ensinam que a política caracteriza-se pela gravidade e pela disjunção.

Maquiavel e Shakespeare projetam o saber histórico e o artístico sobre o campo do pensamento político, desorganizando-o e marcando aí o momento da instauraçăo da modernidade. Neste sentido, eles demonstram que o espaço da política contém desafios e tensóés constantes para todos os homens em qualquer época, superando antigas concepçōes que imprimiam estabilidade ou coerência à política. Um olhar mais demorado e mais exigente deve "ver a ciência com a óptica do artista, mas a arte, com a da vida” (Nietzsche, 1992:15).

Nos textos destes dois autores, que produzem sob inspirações específicas e em épocas diferentes, encontramos um ordenamento de mundo fundado na política (das 27 peças de Shakespeare, 22 tratam de temas políticos, a maioria de forma direta; mesmo as obras literárias de Maquiavel abordam indiretamente a política). Eles entendem que as diferentes formas de exercício do poder dão significados distintos à vida dos indivíduos, à história de uma cidade ou ao destino de um povo. Abrem espaços inusitados para se observar os homens e suas práticas a partir do plano político sem, no entanto, condicioná-las a uma única causa.

A seguir, são apresentados alguns supostos que serão aprofundados na última parte deste texto, utilizando-se como referência básica, mas não exclusiva, $A$ tempestade, pois outras peças de Shakespeare servirão como elementos para conclusōes. 


\section{Um deslocamento da abordagem política: Shakespeare clarificado por Maquiavel}

No presente estudo, a abordagem política destes autores será reconstituída tomando-se como parâmetros a aproximação entre arte e política e a proximidade entre indivíduo e poder. Estes dois aspectos, que podem ser observados com maior ou menor intensidade em determinadas obras, serão os elementos nucleares para analisar a natureza da política em Shakespeare, clarificado por Maquiavel.

No que se refere à relação entre arte e política, é indiscutível que toda obra de Shakespeare constitui-se numa forma de conhecimento expressa na mais alta poesia e dramaturgia produzidas pela civilização. $O$ texto e a literatura compóem o suporte para as idéias deste autor, cuja produção é voltada para a montagem teatral. Maquiavel, por sua vez, também expressou-se pela literatura, através de obras como Cartas florentinas e $A$ mandrágora. Nos dois autores, portanto, encontra-se, na abordagem dos homens e da história, uma sensibilidade aguçada pela arte.

Neste sentido, um estudo que considere a intersecção de Maquiavel com Shakespeare desloca o enfoque político do centro da esfera política para as suas bordas, em que campos limítrofes auxiliam-se mutuamente na compreensão do fenômeno político. Este deslocamento permite novas possibilidades e recursos para conquistar uma posição estratégica ou diferenciada quanto à investigação política. Esta mudança de perspectiva é importante para manter arejada a ciência política, conforme uma indicação apanhada em Maquiavel (1969:12): “... assim como aqueles que desenham a paisagem se colocam nas baixadas para considerar a natureza dos montes e das altitudes e, para observar aquelas, se situam em posição elevada sobre os montes, também para bem conhecer o caráter do povo, é preciso ser príncipe e, para bem entender o do príncipe, é preciso ser do povo".

Uma abordagem shakespeariana trata simultaneamente da política e da sua negação. Neste sentido tal deslocamento, que vincula arte e política, talvez tenha a mesma utilidade de uma interpretação mais objetiva ou científica, em função do significado da vida, conforme o dramaturgo deixa entrever em Macbeth: "Têm iluminado aos tantos que nós somos / nosso caminho para o pó da morte. / Breve candeia, apaga-te! Que a vida / É uma sombra ambulante: um pobre ator / Que gesticula em cena uma hora ou duas / ... Significando nada" (Shakespeare, 1989:111). Ao dar esse sentido à existência, Shakespeare possibilita que a política tenha acesso ao avesso da racionalidade e, ao ser clarificado por Maquiavel, repõe esta possibilidade sob uma ótica realista, que supóe tanto a existência de mecanismos próprios à política, quanto a defesa de uma posição pessoal, no caso, a defesa da monarquia legítima. Assim, a abordagem shakespeariana engloba a dimensão 
subjetiva, afetiva e, portanto, irracional do exercício do poder, bem como a dimensão racional da política. Neste sentido, Shakespeare aponta para outro tipo de contradição que perpassa o político, ao reforçar que o valor das paixóes e emoçóes individuais e as comoçóes coletivas, mesmo ao ocorrerem inconstantemente e aos saltos, de forma extraordinária, não são alheios e nem excepcionais à política. Exatamente, por causa da morte, torna relativo os fenômenos políticos $\mathrm{e}$, por oposição a ela, imprime maior importância à vida e ao homem. Paradoxalmente, contra a degradação humana simbolizada por esse mal absoluto, a política e o homem darão a outra medida da vida. $O$ indivíduo - na sua natureza e humanidade - atravessa a vida defrontando-se consigo mesmo e com o poder, num encadeamento de fatos guiados também pelo destino (acontecimentos sem controle por parte do sujeito, em cujo limite encontra-se a morte). Portanto, os homens agem, mas a ação desenrola-se no interior de um espaço oculto e abstrato a eles. Se o destino tem tal força em Shakespeare, em Maquiavel ganha importância a virtú ou a fortuna, dependendo das circunstâncias.

Desta ampla temática retira-se o segundo aspecto que serve de parâmetro inicial para esse estudo, qual seja, o da proximidade entre indivíduo e poder, que tem raízes no renascimento e corresponde à capacidade destes autores em exteriorizar ao máximo as potencialidades possíveis do indivíduo no mundo. $\mathrm{A}$ experiência do enfrentamento entre homem e poder é limítrofe, desafiadora e inevitável, dada a condição humana e a vida em sociedade. Shakespeare e Maquiavel são autores que permitem lançar um olhar direto sobre quem governa ou sofre a ação de governo, através da presença corpórea, física, destes șujeitos.

O teor dessa experiência, da forma como foi captada em uma leitura shakespeariana com referência em Maquiavel, supõe as características individuais (paixôes, interesses, capacidade ou não de governar, personalidade e outros valores subjetivos), tipificando açóes ou relaçóes políticas. A pessoa - a personagem política - é portadora de um elenco de possibilidades ou limitações utilizado nos embates do espaço político. Desta forma, uma abordagem institucional de Maquiavel e Shakespeare é possível quando tomam-se como parâmetros as questóes de identidade nacional e monarquia legítima, em Shakespeare, e de Estado centralizado, República e unificação italiana em Maquiavel. Contudo, para efeito deste trabalho, não será privilegiada uma abordagem que esteja centrada na questáo da legitimidade do poder. Importa mais apanhar os fenômenos que envolvem homem e poder, na base do processo político, seja ele legítimo ou não. Cada vez mais a ciência política tem se voltado para análises institucionais, privilegiando as questões formais das relações de poder, deixando em aberto áreas que passam a ser ocupadas por outros setores do conhecimento. Uma leitura política de Shakespeare/Maquiavel abre caminhos para se recuperar ou fortalecer uma perspectiva em que o poder possa ser discutido considerando a condição humana, o que reduz, dessa forma, os riscos da burocratização e formalização da análise política. 
Embora sejam significativas as caraterísticas individuais, elas não são suficientes para explicar a experiência política, necessitando do pólo complementar. Esta forma de enfocar indivíduo e poder supōe a existência de dois pólos de forças: as ações humanas e a dinâmica autônoma do poder, que dão origem a um campo dramático centrado no trono do governante. Mais em Shakespeare do que em Maquiavel, o foco é dirigido à pessoa (tradução imediata de um fenômeno laico profundo) que ganha nova dimensão no contato com a esfera do político, seja Macbeth, que vive os conflitos de assassino e usurpador, sejam Romeu e Julieta ou Ofélia, que sofrem o confronto político familiar, seja Ricardo II, destronado do poder. Em Maquiavel, mesmo sendo relevante a figura do homempríncipe, o que mais importa é o sentido da sua ação.

Entre as inúmeras possibilidades de análise de Shakespeare, coloca-se neste estudo aquela que busca nas suas peças o sistema de valores montado por Maquiavel, em que o critério da racionalidade da ação (adequaçáo entre meios e fins) deve se contrapor à conduta individual e moral do agente. Neste sentido, estará sempre presente, nos dois autores, a preocupaçáo com o encontro entre o individual e $o$ coletivo e entre a moral e a política, pois a forma como se resolve esta equação criará ou não focos de tensões no interior do governo ou entre a multidão.

A genialidade destes autores está na capacidade de saltar do individual para o institucional - e vice-versa -, considerando que as paixóes e as irracionalidades, assim como a fortuna e o destino, impregnam a ação política, e que o ritmo do avanço político e as suas razōes exigem o consumo da alma e do corpo. Quanto a este último aspecto, é possível ser detectado claramente no interior da abordagem shakespeariana, pois ela permite apanhar as paixões humanas e as demências coletivas da história.

Por isto mesmo, ao se vincular a abordagem shakespeariana a Maquiavel, cria-se um espaço de encontro entre política e vida, cujo pano de fundo é a presença constante da tragédia. Uma visão de Shakespeare, clarificada pela leitura de Maquiavel, une arte e política, homem e poder, assim como caos e controle, vida e morte.

\section{A ilha do poder $-A$ tempestade}

Um estudo da concepção shakespeariana do poder e da política, bem como uma comparação com os ensinamentos de Maquiavel podem ser feitos a partir da maioria das peças de Shakespeare, conjuntos ou unidades, independentemente do fato deste autor ter ou não tomado conhecimento e assimilado os ensinamentos do pensador florentino.

A tempestade, selecionada para fins deste estudo, é uma obra que permite 
apanhar a dimensão política expressa na produção shakespeariana, valorizando não apenas as suas características internas, mas também algumas formulaçốes de Maquiavel. Esta última peça de Shakespeare foi publicada em 1611 e possui algumas particularidades que a tornam exemplar para servir aos objetivos aqui propostos. $A$ tempestade situa-se num ponto eqüidistante das obras históricas, das tragédias e das comédias, e embora apresente traços das demais, adquire um forte sentido metafórico, constituindo-se quase numa construção do essencial dos mecanismos de poder e das relaçóes políticas. A dramaticidade das personagens, a carga poética do texto ou até a demasiada humanidade podem estar reduzidas na peça, mas, em contrapartida, as personagens e as cenas sintetizam significativas situações políticas.

Enquanto produção derradeira de Shakespeare, é como se o poeta tivesse aí apurado o seu conhecimento, aprofundado a compreensão de política e assimilado o fundamental de Maquiavel para apresentar um painel realista da ilha política. Cria-se, então, um modelo de armação do poder, em que a presença de elementos da história é reduzida para reforçar as relações e a estrutura política. Shakespeare coloca à disposição um esquema complexo e aberto que multiplica as possibilidades da análise.

A tempestade mostra o governo instaurado por Próspero, em uma ilha, após ter sido destronado do Ducado de Miláo por seu irmão Antonio, pactuado com o rei de Nápoles. Em seguida à usurpação, ele é colocado, com sua filha Miranda, num barco (com alguns livros e mantimentos, graças à nobreza de Gonçalo) que, à deriva, os conduz até a ilha. Mais tarde, já de plena posse de novos poderes, a generosa fortuna permite que Próspero se vingue dos usurpadores, quando eles estão navegando nas costas da ilha. Próspero arma uma tempestade e com a ajuda de Ariel, o espírito servidor, manipula os destinos dos náufragos, que conseguiram chegar às praias da ilha, também habitada por outros espíritos e por Caliban, escravo peçonhento.

Encontramos uma sitúação em que Próspero, usando de sabedoria e magia, controla completamente os habitantes do seu reinado, a fim de subjugar o mal, reconciliar as disputas do passado, fechar o ciclo pecado/regeneração/penitência e avançar para um modo de vida mais civilizado (Traversi, 1964:81).

A ilha deixa entrever um novo mundo, uma vez que, entre várias inspiraçóes em Virgílio, Ovídio e Erasmo, Shakespeare utiliza-se claramente dos Ensaios de Montaigne e dos relatos de Viagens à América (Ilhas Bermudas e Virgínia) como, por exemplo, o relatório de William Strachey (Muir, 1964: 90-91). Esta atmosfera de uma ilha entre a Europa e a África imprime um tom tropical à peça de Shakespeare. As seguintes passagens exprimem este cenário criado pelo dramaturgo: "A natureza por si mesma alimentaria o meu povo inocente, com fartura e 
abundancia (...) Frutos da terra e mais plena ventura,/ Celeiros sempre cheios com farturas,/ Vinhas de cachos sempre numerosos/ Árvores só de frutos saborosos" (Shakespeare, 1991:69 e 125).

A tempestade trata de uma espécie de principado novo: "Estes domínios assim obtidos estão acostumados, ou a viver submetidos a um príncipe, ou a ser livres, sendo adquiridos com tropas de outrem ou com as próprias, bem como pela fortuna ou por virtude" (Maquiavel, 1969:13). Próspero, graças à fortuna, estabelece na ilha um principado totalmente novo:

"Próspero: ... Haviam preparado um barco de carcaça podre, sem instrumentos, sem vela, sem mastro...

Miranda: Como chegamos à terra?

Próspero: Por graça da divina Providência" (Shakespeare, 1991:33).

Também a virtude foi importante para o estabelecimento do principado de Próspero, como se vê através da seguinte passagem:

"Caliban: (a parte) Tenho que obedecer. Sua arte é tão poderosa que seria capaz de dominar Setebos, o Deus de minha mãe, e transformá-lo em seu vassalo" (Shakespeare, 1991:49). No exercício da prática política, o temor do súditos mostra a efetivação do poder do príncipe.

Na situação do principado já estabelecido na ilha, dois temas ganham importância fundamental na descrição política da ilha: a submissão e a liberdade. Compóe-se um intrincado triângulo, em que Próspero representa a autoridade que ordena a ilha, com capacidade de libertar e escravizar e Ariel e Caliban agem das mais diferentes formas, supondo a possibilidade da liberdade. Ariel traduz 0 espírito da liberdade, mesmo tendo sido servo outrora, e Caliban representa a escravidão, mesmo já tendo sido livre.

A tempestade releva a discussão de liberdade e poder, ampliando a abordagem para a relação mando/obediência, o que envolve a questão não só do exercício do poder, mas também da qualidade do povo. Neste caso, referências a Comentários sobre a primeira década de Tito Lívio, de Maquiavel (1979), tornam-se importantes para uma análise comparativa. Nesta obra, desde o $1^{\circ}$ capítulo, que trata da cidade fundada na liberdade e da escolha livre dos homens, até o capítulo 58, que aborda o caráter e a paixão do povo, encontram-se elementos que permitem reinterpretar Ariel e Caliban, como símbolos dos súditos de Próspero.

Para Maquiavel, "não se tem, portanto, o direito de criticar o caráter da multidão, como o dos príncipes; todos estão sujeitos aos mesmos erros, quando não há freio que modere as paixões (...) Um povo que tem o poder, sob o império 
de uma boa constituição, será tão estável, prudente e grato, quanto um príncipe (...) A crueldade da multidáo se dirige contra aqueles que suspeita quererem usurpar o bem geral; a crueldade do príncipe persegue todos os que considera inimigos do seu bem particular” (Maquiavel, 1979:180-187). A relaçâo triangular estabelecida na ilha é instável porque a obediência dos súditos é dirigida ao príncipe de forma diferenciada - contendo desde a prudência até a crueldade. Se Ariel modera suas paixões e se mostra prudente, o mesmo não acontece com Caliban que estabelece uma relação apaixonada e cruel com o príncipe. Neste sentido, conta Shakespeare em $A$ tempestade:

"Próspero: ... O que queres pedir?

Ariel: A minha liberdade.

Próspero: Antes do prazo? Nem pensar.

(...)

Próspero (a Ariel): Serás tão livre quanto o vento das montanhas. Mas deves seguir rigorosamente as minhas ordens

(...)

Caliban (a Próspero) ... Esta ilha é minha, porque foi de Sycorax, minha mãe. E tu a tomaste de mim ... Porque eu, que sou teu único súdito, era antes meu próprio rei. E aqui me aprisionaste neste rochedo, enquanto te apossas do resto da ilha.

Próspero: escravo mentiroso, que só caminha a custa de chicote, nunca de agrados! Embora fosses imundo, tratei bem de ti e abriguei-te em minha própria gruta, até o dia em que tentaste violar a honra de minha filha" (Shakespeare, 1991: ato I, cena II).

Ariel, servo que busca a liberdade obedecendo e agradando, e Caliban, escravo que quer recuperar a liberdade através de maldiçóes e conspiraçóes, expressam uma unidade que serve para simbolizar as diferentes atitudes da multidão ou do povo com relação à autoridade. Se a obediência de Ariel deve-se à promessa e à esperança da liberdade, a transgressáo da ordem por parte de Caliban indica que a liberdade natural ou gozada por desejos ou paixóes individuais coloca em perigo a sociedade, justificando o castigo como uma forma de escravização do mal.

Desta forma, a perspectiva da liberdade passa a se constituir no fundamento das açóes políticas das personagens. Através desta tríade de personagens, Shakespeare monta uma equação maquiavélica, em que a relaçáo entre Próspero e Ariel significa o vínculo baseado no consentimento, situação que permite ao povo e ao príncipe estabelecerem laços de confiança e aceitação mútua. Já a relação entre Próspero e Caliban reforça a existência, na política, do vínculo baseado na coerção e na violência. A liberdade, no primeiro caso, deverá ser conquistada no âmbito definido pelo poder $\mathrm{e}$, no segundo, deverá ser buscada através da escravidão. 
A liberdade aparece como anjo transformador tanto para um quanto para o outro. A cada ordem que Ariel cumpre, Próspero acena com promessas de liberdade: "Daqui a pouco os meus trabalhos chegarão ao fim, e alcançarás o ar em liberdade", ... "Daqui a pouco, serás livre", ... "Vou sentir a tua falta. Mas, ainda assim, terás a liberdade" (Shakespeare, 1991:135, 141, 147). Caliban, por sua vez, não esmorece em face da sua escravidão, amaldiçoa porque se não fizer o que Próspero manda será atormentado ("Se não fizeres o que mando hei de atormentar-te com câimbras de velho e torturar teus ossos. Farei com que lances rugidos de amedrontar as feras" - Shakespeare, 1991: 49). Por isso, Caliban conspira para destronar Próspero (Caliban para Estéfano: "Com seus feitiços, como eu dizia, ele se apoderou desta ilha. Tomou-a de mim. Se quiseres promover minha vingança, alteza - pois sei que tens coragem ... Dentro de meia hora, ele estará dormindo. Irás, então, acabar com ele?" - Shakespeare, 1991:103-107). Ariel obedece enquanto indivíduo livre, para obter um outro tipo de liberdade. Caliban, meio bicho que é, deseja se ver livre de Próspero, mesmo que para tanto tenha de servir a um outro senhor.

Desta forma, Caliban e Ariel permitem discutir a irracionalidade e a racionalidade presentes entre os governados. Caliban percorre o circuito livre ignaro - escravo, por deixar aflorar a irracionalidade, o espírito não-cooperativo e a conspiração. Em contrapartida, Ariel busca a liberdade de forma racional, estipulando, para si próprio, que a obediência às demandas do poder instituído garantir-lhe-á a liberdade. Trata-se da liberdade concedida: serás livre, desde que obedeça as ordens!

Tanto Ariel quanto Caliban experimentaram as liberdades natural e interna, pois o primeiro era um espírito delicado, que foi aprisionado por Sycorax por não executar suas ordens baixas e abomináveis; o segundo, em outros tempos, foi seu próprio rei. Buscam agora, pela vontade, recuperar a liberdade reduzida ou perdida, reagindo a cada nova situação pela razão ou pelo instinto.

É por esse motivo que a liberdade aparece na peça enquanto perspectiva de mudança para o indivíduo, no mesmo sentido em que a tempestade é a metáfora da força capaz de operar as grandes transformações.

E, paradoxo crucial: Próspero, ao final da peça, após realizar a sua vingança e repor a ordem política e social, deixa entrever que ele também busca e deseja a sua liberdade, pedindo a indulgência de estar livre:

"Meu poder já não existe,

Só minha força persiste

Mereço escapar à pena. 
Tanto os súditos quanto os governantes vivem em constante tensão. Para os que governam, a experiência do exercício do poder tem tal magnitude que a liberdade acaba sendo almejada mesmo por quem é governante. $O$ epílogo de $A$ tempestade insinua ou o desejo de Próspero evadir-se de uma ilha onde é a autoridade única, ou a proposiçăo da morte como a liberdade possível. Paira, ao final da peça, um certo desencanto que traduz outras situaçóes, nas quais o poder pode causar frustração (Próspero), senão conduzir à loucura (Lady Macbeth) e à morte (Hamlet). Por sua vez, para os governados, o gozo da liberdade será sempre insuficiente, tendo que buscá-la constantemente. Os súditos vivem premidos entre a expectativa ou esperança da liberdade e a necessidade da obediência ou confirmação da autoridade.

Próspero simboliza o poder capaz de "ofuscar o sol do meio-dia", um príncipe condutor e criador de uma nova ordem. Instaura a sua moral e impóe a sua vontade, exigindo obediência e manipulando fatos e vidas. O poder político pode ser exercido de diferentes maneiras e em circunstâncias diferenciadas, sendo que para Shakespeare a sua evolução significa avançar rumo a um ordenamento legal e justo. $O$ poder desta personagem tem origem mundana e está intrínseco às relações humanas, tornando-se maior ainda pela arte e pela magia do antigo Duque de Miláo. Tendo poder (que, neste caso, supóe conhecimento), ele sabe muito a respeito de seus súditos, conhece os segredos da natureza e situa-se inteligentemente neste conjunto que é a ilha. Assiste a tudo sob uma ótica privilegiada, o que facilita a sua ação. Com seus espíritos que vagueiam pelas ilhas, este soberano, lembrando La Boètie, tem milhares de olhos e pernas.

O soberano da ilha passou por uma série de experiências políticas que o transformaram de um homem contemplativo em um político de ação. No Ducado de Milão, conforme interpretação tomada de Maquiavel, pode-se dizer que, embora amado pelo povo, era um mal governante, pois era incapaz de governar. Já na ilha o encontramos como um bom governante, porque obedecido, temido e odiado pelos súditos. As passagens abaixo marcam estas variaçóes do tempo e da qualidade política da personagem:

Próspero: "Antônio ... a quem eu amava quase tanto quanto a ti (Miranda), a quem confiei os negócios do meu Estado -, que era, na época, o melhor de todos, e Próspero o mais digno entre os duques, dedicado como nem um outro às artes liberais, cujo estudo me consumia tanto que deixei os encargos de governo para meu irmão. Fui me tornando estranho a meu Estado, absorto, exilado em meus estudos secretos. $\mathrm{E}$ o traidor do teu tio - Estais escutando?

(...)

Próspero: Assim, desatento às coisas do mundo, dedicado à solidão e ao 
aperfeiçoamento do espírito, que, embora me impusesse o isolamento era uma forma superior de saber, despertei em meu irmÃo uma natureza perversa.

(...)

Próspero; ... Ele acabou acreditando que era o verdadeiro Duque. Esqueceu-se de que era meu substituto e assumiu a máscara da soberania, com todas as prerrogativas...

(...)

Próspero: Para que não houvesse nenhum véu entre o papel que desempenhava e o seu próprio desempenho, decidiu tornar-se senhor absoluto de Miláo. Quanto a mim, pobre coitado - minha biblioteca era um ducado suficientemente grande -, ele considerou que eu não era capaz de governar; sedento de poder, aliou-se ao Rei de Nápoles" (Shakespeare, 1991:29 e 31).

No Ducado de Milāo, Próspero era um homem poderoso, mas cujo poder era restrito à sua biblioteca, não sabendo utilizar o poder político de forma realista e racional. Próspero reconhece frente à filha Miranda que amava os livros e que prezava mais a biblioteca do que o seu ducado. $\mathrm{Na}$ verdade, era um governante de natureza moral voltado ao estudo e ao conhecimento. Pode-se perceber aí uma tensão entre conhecimento e açáo política, como Shakespeare já apontara em Hamlet. Neste sentido, Nietzsche diz que, "o homem dionisíaco se assemelha a Hamlet: ambos lançaram alguma vez um olhar verdadeiro à essência das coisas, ambos passaram a conhecer e a ambos enoja atuar; pois sua atuação não pode modificar em nada a eterna essência das coisas, e eles sentem como algo ridículo e humilhante que se thes exija endireitar de novo o mundo que está desconjuntado" (Nietzsche, 1992:56).

Cabem, neste sentido, algumas observaçōes. Primeiro, torna-se mais clara a situação expressa por Próspero no epílogo: um homem que chegou à essência das coisas vê-se obrigado, pelas circunstâncias, a exercer o poder político, a agir como um príncipe novo. Na ilha, Próspero pretende endireitar de novo o mundo, mesmo enojado de atuar. Também deve-se observar que a forma pela qual Próspero enfrenta agora os desafios subjetivos e políticos representa um avanço em relação às dúvidas hamletianas, permitindo afirmar que um intelectual, um mágico ou um artista dispõem-se a decidir e a executar ações políticas de forma realista, sem tornarem-se vítimas das dúvidas durante o exercício político. $\mathrm{Em} A$ tempestade o livro e a biblioteca aparecem com valores simbólicos relevantes. Tanto que, Caliban, durante a conspiração, informa a Estéfano que antes de assassinar Próspero, antes de tudo, "não te esqueças de tomar seus livros. Sem os livros, ele não passa de um idiota como eu" (Shakespeare, 1991:105). Aliás, esta ênfase dos ensinamentos dos livros pode merecer um estudo específico para analisar o aspecto esotérico que se encontra em $A$ tempestade. Eles são fontes de saber e poder que ampliam a capacidade de decisão e ação do sujeito e servem para destrinchar a realidade. 
Contudo, ao final da peça, sente-se que as contradiçōes daí nascidas estão prestes a desmoronar aquele que ofusca o sol do meio-dia.

Na ilha, Próspero governa com a sorte - "árbitro de nossas ações" - e com a virtú, "a outra metade", conforme ensina O príncipe (Maquiavel, 1969:146). Passa da contemplação para a ação decidida: "Considero seja melhor ser impetuoso do que dotado de cautela, porque a fortuna é mulher e, conseqüentemente, se torna necessário, querendo dominá-la, bater-lhe e contrariá-la; e ela mais se deixa vencer por' estes do que por aqueles, que procedem friamente. A sorte, porém, como mulher sempre amiga dos jovens, porque são menos cautelosos, mais afoitos e com maior audácia a dominam" (Maquiavel, 1969:148).

$\mathrm{O}$ antigo Duque de Milão não era um arqueiro hábil que considerava $o$ ponto distante a atingir, nem media a capacidade do arco e nem usava da boa mira, como escreve Maquiavel, no capítulo VI de $O$ principe, quando mostra a necessidade da racionalidade governamental. Mas, na ilha, a situação é bem diferente, pois aí Próspero descobre que "...nas açôes de todos os homens, em especial dos príncipes, ... o que importa é o sucesso das mesmas. Procure pois um príncipe, vencer e manter o Estado: os meios serão sempre julgados honrosos e por todos louvados" (Maquiavel, 1969:109).

Na nova situação da ilha, o ex-Duque de Milão utiliza-se, principalmente, do seu conhecimento para a ação política, o que facilita dominar a natureza, os homens e as coisas. Neste caso, pode-se perceber um outro tratamento para a questão que envolve conhecimento e ação política, uma véz que o saber pode auxiliar a prática. Calculadamente e usando de sua arte, ele ocupa a ilha de Sycorax, escraviza o filho herdeiro, controla os espíritos da ilha, ordena tempestade, manipula as vidas do irmão Antônio, do rei de Nápoles e de quantos os acompanham, interfere no amor de Miranda e Fernando, julga e perdoa. Enfim, obtém sucesso ao colocar o tempo novamente nos eixos.

Próspero exerce na ilha o poder absoluto e de forma eficiente, desconsiderando até os apelos da filha que suplica pelo amado Fernando. Assim, torna-se um príncipe que tem presente os ensinamentos políticos de Maquiavel, em que a racionalidade é central, tendo em vista os objetivos a que se propõe. A política não é só uma forma de conhecimento, mas é também técnica a ser aplicada, avaliando-se cada momento, situação e oportunidade. É na prática que ela se configura enquanto tal. A história corre e transforma-se constantemente, através de conjunturas que deixam aparecer amigos e inimigos, desnudam conspiraçóes, golpes e perigos os mais diversos, conforme lista Maquiavel. O tempo político é o tempo da instabilidade e dos desequilíbrios, diferente do tempo natural de Sycorax, parado e constante e do tempo da obtenção do conhecimento na biblioteca. 
Ao descrever os devaneios e a ingenuidade de Gonçalo, que sonha com a sociedade ideal ("Em minha nação, eu faria tudo pelo avesso. não permitiria nenhuma espécie de comércio, nem nomearia juízes... Nada de governo" Shakespeare, 1991:69), e as reações sarcásticas dos companheiros, Shakespeare coloca em confronto as idéias do nobre e sonhador Alonso e a movimentação golpista na cena seqüencial. Enquanto o primeiro continua a ter atitudes morais, Shakespeare mostra que o poder político prossegue em pleno funcionamento, atraindo os homens para novas conspirações. A sociedade ideal de Alonso, em que tudo seria o contrário, sucumbe ao realismo permanentemente da política.

As ações dramáticas de $A$ tempestade são pontuadas por três conspirações. A história tem início com a conspiração de Antonio que alija Próspero do trono de Milão, o que deflagra e dá significado à peça. Antonio e Sebastião, náufragos na ilha, também conspiram contra Alonso, Rei de Nápoles: Sebastião para Antonio - "Teu caso, meu caro, me servirá de exemplo. Assim como ganhaste Miláo, ganharei Nápoles. Desembainha a espada. De um golpe, estarás livre do tributo que pagas. E eu, o Rei, serei teu amigo" (Shakespeare, 1991:79). A terceira conspiração, também descrita em minúcias por Shakespeare, envolve Caliban e Estéfano contra Próspero: Caliban para Estéfano - "Como eu ia dizendo, ele costuma dormir tarde. então depois de tomar-lhe os livros, poderás rebentar os miolos dele. Ou dar-lhe uma paulada na cabeça" (Shakespeare, 1991:105). A constância de ocorrência de conspiraçóes serve para Shakespeare alertar os homens e os governantes do seu tempo à respeito deste risco da política, como o faz através da voz de Ariel: "Enquanto segues dormindo/ Vai a intriga progredindo/ E cresce e engorda!/ Se à vida estás apegado,/ Sacode o sono, e cuidado:/ Acorda, acorda!" (Shakespeare, 1991:79). Deve ser reforçado, ao se deter sobre as conspiraçóes, que Macbeth é um grito contundente a respeito dos tronos manchados de sangue. Como contraponto, não se deve esquecer que Maquiavel, reportando-se à realidade política, lembra da importância dos meios para se atingir fins, reconhecendo que "por qualquer meio criminoso e nefário se ascende ao principado...", e cabe "a quem de tal necessitar, apenas imitá-los" (Maquiavel, 1969:55).

Em Shakespeare, como em Maquiavel, o poder está sempre atraindo os homens - na maior parte das vezes a uma armadilha. A política constitui uma esfera com regras próprias, com tal intensidade, de forma que poucos resistem a seus efeitos. Pode até ser que a natureza do regime político (monarquia ou república) e os objetivos do exercício do poder (centralização, unificação, bem comum) atenuem o governo de um príncipe virtuoso ou afortunado (melhor se for os dois). Caso contrário, governar torna-se um pesadelo, senão um inferno.

A política pode ser uma atividade construtora ou devastadora, atingindo príncipes e súditos. Próspero vive uma experiência positiva de política e mesmo assim deixa-se esmorecer - "o meu fim é o desalento", testemunha ao final da 
peça. No pólo oposto, encontra-se Macbeth, experiência que traduz o poder devastador, o significado negativo da política. O trono conquistado por Macbeth, graças a conspirações e assassinatos, o conduz à tirania calculada, ao esforço para conter conflitos internos e, finalmente, à própria destruição: "Ter consciência/Do ato que pratiquei - melhor seria/Perder conhecimento de mim mesmo!" (Shakespeare, 1989:40). Se a legitimidade ou bons objetivos conseguem criar um tênue anteparo ao campo gravitacional gerado pelo poder, o mesmo não acontece com o poder usurpado e despótico que leva à destruiçăo aqueles que o ocupam ou vivem sob ele.

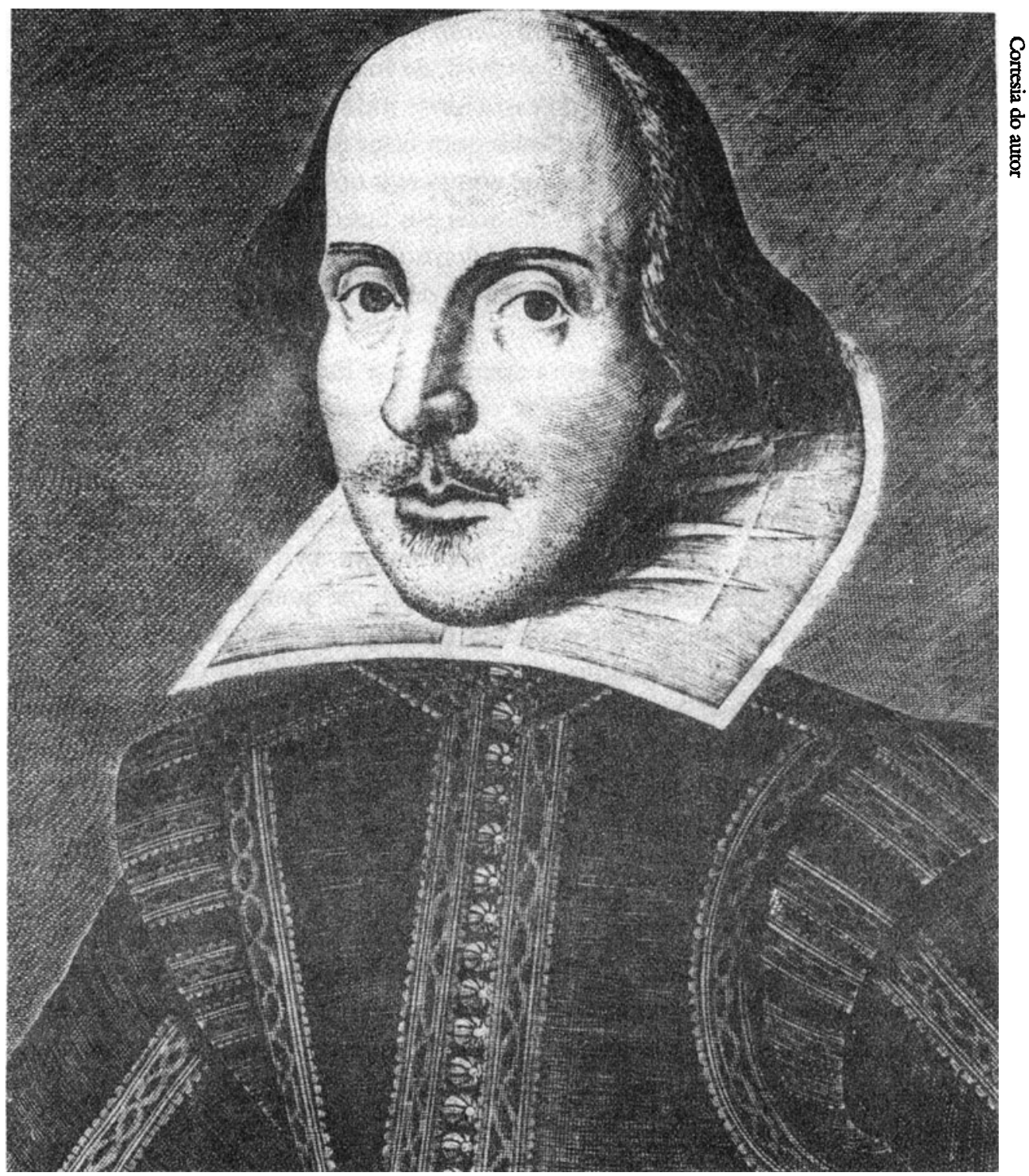

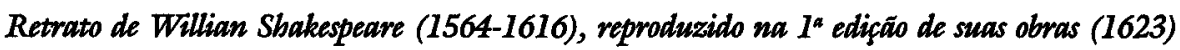


Talvez Macduff tenha tentado traduzir aquilo que nunca é mostrado diretamente, mas percebido apenas nos mecanismos de mando, regras e leis, quando abre a porta do aposento e vê o rei apunhalado:

"Oh horror! horror! horror!

Boca nem coração poderão nunca

Nomeá-lo ou concebê-lo!” (Shakespeare, 1989:43).

\section{A política como arte e a arte política}

Em Maquiavel, a política é permanente ação e a arte constitui o resultado das ações individuais e dos esforços coletivos. As manobras para a manutenção e segurança do poder exigem o uso da capacidade individual em grau elevado. "O restante deve ser feito por vós. Deus não quer fazer tudo, para não nos tolher o livre arbítrio e parte daquela glória que compete a nós" (Maquiavel, 1969:150151). Neste sentido, muito resta aos homens por fazer, principalmente no que se refere às açóes políticas, sejam as dos poderosos, sejam a dos governados que deveriam aprender os mesmos ensinamentos dados ao príncipe.

Entretanto, a política não gera apenas a arte individual, mas, também, a arte coletiva, aquela manifestada pela cidade, como por exemplo, o caso de Roma, onde "seus legisladores e a ordem pública que instituíram" deixam espantados os seus estudiosos ao "saber que tantas virtudes tenham sido ali cultivadas durante séculos" (Maquiavel, 1979:19). A política traduz-se em arte quando o príncipe, agindo pelo livre arbítrio, faz com que a virtude dome a fortuna, entendendo racionalmente os fatos circundantes, ou quando uma cidade produz boas leis, baseadas nos bons costumes e nos canais institucionais para participação dos cidadãos, tornando então possível a fundação de um governo republicano. Tanto para o indivíduo (virtuoso) quanto para o povo (sábio), a política é, metaforicamente, uma arte de homens em liberdade, exatamente pelo esforço e pelo conhecimento exigidos para regrar açóes, gerir Estados e aperfeiçoar a sociedade contra as armadilhas e dificuldades do destino - e na política elas são intermináveis.

Para Shakespeare, a arte encontra sentido na política à medida que esta dilui-se na vida. A política deve ser recuperada para melhor desvendar os segredos do homem e da sociedade. A arte política não está voltada diretamente à ação, mas adquire sentido enquanto forma de conhecimento e de consciência, propondo a reflexáo para a compreensão do eu e do outro. "Quanto a mim, pobre coitado - minha biblioteca era um ducado suficientemente grande ...". "Vou quebrar o encantamento e devolver-lhes a razão ..." - diz Próspero, em várias passagens de $A$ tempestade, referindo-se sempre à sua magia ou à arte. 


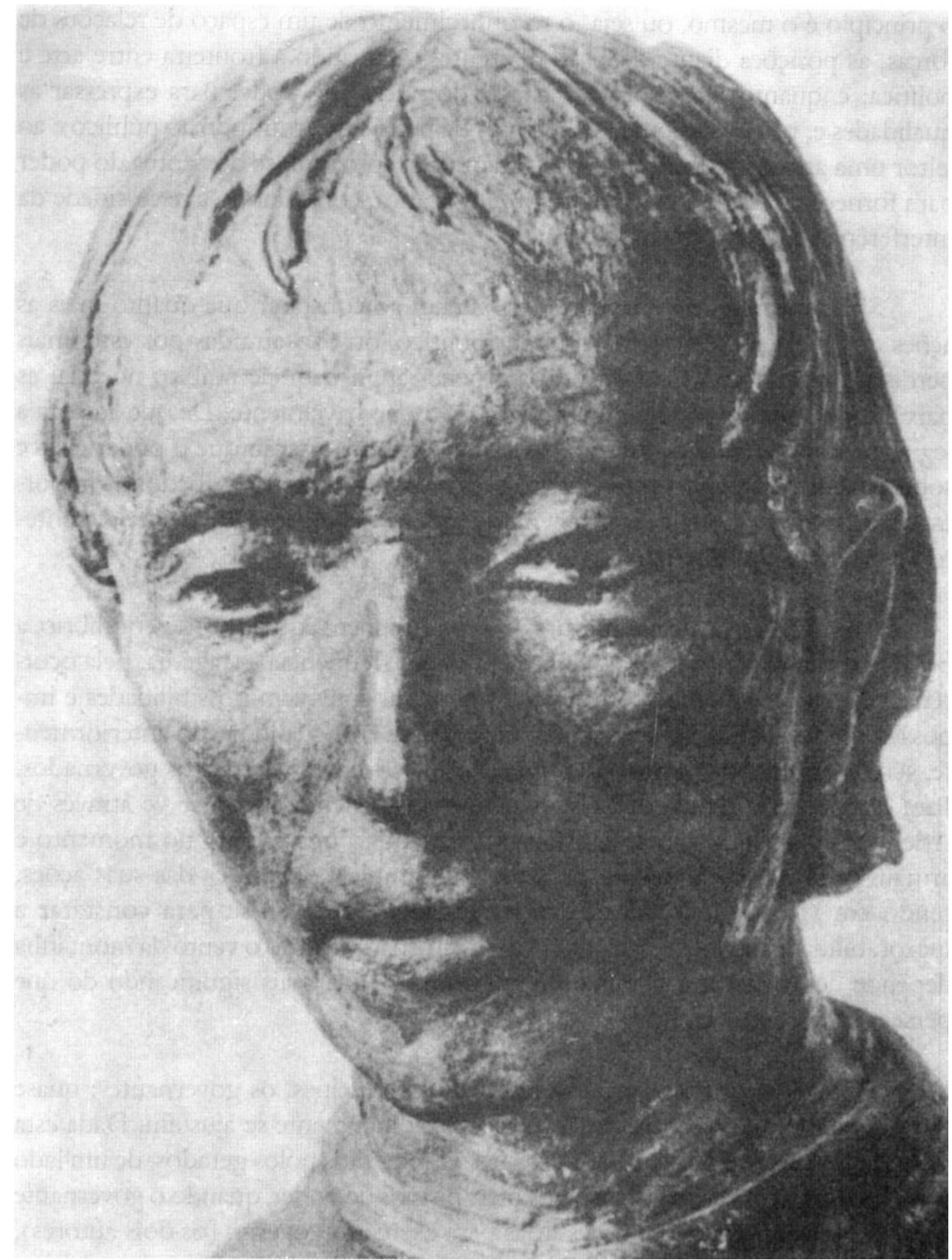

Busto de Niccolò Machiavelli (1469-1527), o Maquiapel, autor do clássico O Príncipe (1513)

Mas é comum aos dois autores o reconhecimento da existência de regras próprias de funcionamento do poder político enquanto instância de forças, traduzindo esta constatação ou através do texto poético, hierarquizando a vida em primeiro lugar - no caso de Shakespeare -, ou através do texto sistematizado com base na história, hierarquizando a política no mais alto patamar. Neste sentido, se 
o princípio é o mesmo, ou seja, o reconhecimento de um espaço de relações de forças, as posições diante dele são diferentes, marcando a fronteira entre arte e política: enquanto Shakespeare afasta-se do núcleo do poder para expressar as qualidades e, principalmente, os horrores da política, permitindo ao público e ao leitor uma atitude reflexiva e crítica, Maquiavel aproxima-se do centro do poder para fornecer teoria e conselhos de ordem prática, constatando a necessidade da interferência nos mecanismos políticos.

Shakespeare e Maquiavel se aproximam ao constatar que quanto mais as ações dos homens se voltam ao poder político, ou São atraídas por este, mais perdem o controle das suas açóes, até penetrarem naquele âmbito no qual as paixões, ou a razão, podem ser subjugadas irremediavelmente. De que adianta a legitimidade de Duncan, Rei da Escócia, em face da atração que o poder exerce sobre Macbeth? Quando surtirá efeito os apelos de Maquiavel, sabedor da importância da unificação italiana para evitar guerras e desagregações, diante dos interesses e limites de Lorenzo de Medici?

Como sucessão de conjunturas que avançam em equilíbrio-desequilíbrio, a política torna-se uma área na qual irrompe com freqüência a tragédia, pela ocorrência de acontecimentos contrários e porque aí convivem possibilidades e impossibilidades. A relação entre liberdade e poder, como já indicado anteriormente, serve para elucidar parte desta tragédia que atinge os súditos, os governados. Para estes o gozo da liberdade será sempre insuficiente, como se vê através de Ariel e Caliban, que não se satisfazem com aquilo que é dado no momento e armam-se de novos ânimos e projetos para ampliar os limites das suas ações, tendo em vista a liberdade. Estes personagens prestam-se para constatar a inexorabilidade da obediência, uma vez que tornar-se como o vento da montanha depende de obedecer e livrar-se de um senhor, nada mais significando do que perseguir um outro senhor.

A tragédia política perpassa também os príncipes, os governantes: quase sempre homens e poder que estão próximos, dificilmente se ajustam. Dada esta situação de tensão é provável o confronto entre os dois pólos gerados, de um lado por ações humanas e, de outro, pelos mecanismos de poder, quando o governante não possui as qualificações necessárias para exercer o governo (os dois autores), ou não age sob a ética própria da política (Maquiavel) ou ainda quando o destino decide atritar estas duas esferas (Shakespeare).

Uma lição comum dos dois autores é que ninguém sai incólume de uma experiência política - nem governante, nem povo, na medida em que a política é uma esfera em que se defrontam natureza e qualidades humanas contra lógica e forças políticas. Shakespeare privilegia a abordagem da política enquanto ativida- 
de humana e, assim, preocupa-se pela maneira como os indivíduos são afetados pelo exercício do poder. Maquiavel, por sua vez, direciona os seus escritos para a compreensão da ação, tendo em vista ampliar a eficiência e a capacidade prática do político e do povo.

Ambos querem evitar a tragédia, já que os homens podem fundar ou manter relaçóes políticas que minimizem as implicações da inevitável presença do poder político, contando, para tanto, com a valorização do bem comum, do regime republicano ou da monarquia legítima.

Assim, enquanto para Maquiavel a realidade pode ser perscrutada de forma direcionada, permitindo o conhecimento para correção e controle político, através de projetos racionais, para Shakespeare a realidade fragmenta-se em pedaços que interagem, como política, amizade, amor, loucura, sonho, religiáo e morte. Maquiavel volta a sua atenção fundamentalmente para a esfera do político, fazendo reduções a partir dela, até mesmo porque são levados em consideração os mais diferentes valores morais, principalmente ao ampliar as potencialidades da ação política. Shakespeare, por sua vez, adiciona valores morais à política, criando tensóes dramáticas no cenário político.

Nos dois autores pode-se perceber uma visão de história cíclica, pois o poder não permite a estabilidade e nem é continuamente exercido por um homem ou por um regime. Príncipes degenerados em tiranos, presença de facções, corrupções e incapacidades no uso do livre-arbítrio são fatos concretos que; em Maquiavel, conduzem a repetidas trocas de governo no percurso da história. Homens tornando-se bons príncipes (Júlio César), conspirando e usurpando o trono (Macbeth), exilados e vitoriosos (Próspero), destronados e de novo um homem comum (Ricardo II), aproveitadores do vazio político (Fortinbras), súditos que buscam a liberdade (Ariel, Caliban) e guerras entre Estados servem para Shakespeare mostrar a eterna e vão substituição cíclica no poder político - os homens são simples atores ou sombras, que passam no palco político, enquanto o poder continua em cena.

Neste sentido, para os dois autores, a tragédia política $e$, além desta constante reposição de energias humanas, a certeza do inesperado, o esforço para evitar o inevitável, a busca da ordem e da harmonia, em face do desequilíbrio e do caos. Nesta situação, o homem moderno cinde-se inexoravelmente ao alçar a esfera política. Shakespeare, aceitando de Maquiavel tanto o realismo político quanto a necessidade da compreensão da natureza humana para melhor entender a a política, expressa em suas obras uma visão exacerbada das tensões e paradoxos dos homens divididos entre a moral e a política e entre a paixão, a irracionalidade e a política. 
Em alguns momentos, os homens encontram-se nas mãos das paixóes $\mathbf{e}$ dos desejos dos governantes, em outros na dependência do incontrolável jogo de forças do poder. Shakespeare, após perceber esta crucial situação, a partir de Maquiavel, examina, então, o espaço político, desnudando o impacto destas duas constataçóes para concluir que não há portas de saída.

Shakespeare faz uma retomada de Maquiavel, envolvendo a política com a vida e com as condiçóes de humanidade e, desta forma, coloca novas questóes e improbabilidades das quais, ainda hoje, não conseguimos escapar. Até mesmo porque "Somos dessa matéria de que os sonhos são feitos. E a nossa vida breve é circundada pelo sono" (Shakespeare, 1991:129).

\section{Referências Bibliográficas}

SHAKESPEARE, W. A tempestade. Rio de Janeiro, Relume Dumará, 1991.

SHAKESPEARE, W. Macbeth. São Paulo, Brasiliense, 1989.

SHAKESPEARE, W. Hamlet. Porto Alegre, L.P.M. Editores, 1988.

MAQUIAVEL, N. O principe. Rio de Janeiro, Civilização Brasileira, 1969.

MAQUIAVEL, N. Comentários sobre a primeira década de Tito Livio. Brasília, Universidade de Brasília, 1979.

TRAVERSI, D. A Tempestade. In: William Shakespeare - IV Centenário. Rio de Janeiro, Ed. Leitura, 1964.

MUIR, K. As fontes da tempestade. In: William Shakespeare - IV Centenário. Rio de Janeiro, Ed. Leitura, 1964.

NIETZSCHE, F. O Nascimento da tragédia. São Paulo, Cia. das Letras, 1992.

MORIN, E. Entrevista. Folha de São Paulo, 12 dez. 1993.

Miguel Chaia é professor do Departamento de Política e do Programa de Pós-Graduação da Pontifícia Universidade Católica de São Paulo (PUC-SP) e editor da revista São Paulo em Perspectiva, da Fundação Seade.

Palestra feita pelo autor em 21 de outubro de 1994 no IEA-USP. 